\title{
MODERNISASI KOTA DAN BENCANA WABAH MALARIA DI CIREBON TAHUN 1930-AN ${ }^{1}$ \\ City Modernization and Malaria Outbreak in Cirebon 1930s
}

\author{
Imas Emalia \\ Prodi Sejarah dan Peradaban Islam, Fakultas Adab dan Humaniora, UIN Syarif \\ Hidayatullah Jakarta \\ Jalan Tarumanegara, Pisangan, Ciputat Timur, Tangerang Selatan, Banten \\ e-mail:imas.emalia@uinjkt.ac.id
}

Naskah diterima: 17-02-2021 - Revisi terakhir: 22-07-2021

Disetujui terbit: 30-11-2021 - Tersedia secara online: 30-11-2021

\begin{abstract}
This article aimed to explain the process of urban modernization and malaria outbreak in the colonial era. The emphasis on modernization is based on several documents from the Nederlandsche Indies government regarding the formation of cities in Java which prioritized infrastructure development for economic that so triggered the malaria outbreak, especially in coastal areas and plantations. This modernization program based on economic industrialization has influenced the economic people, workers, traders, employees, and healers. In the process of modernization, the emergence of the malaria outbreak spreads to the people. Therefore, the focus of this research analysis is on the modernization process and malaria outbreak in Cirebon in the colonial era. It is important to note that modernization does not does not always produce cultural products that have a positive impact. In addition, it is also for the assumption that the malaria outbreak is an environmental problem due to ignorant public health problem.
\end{abstract}

Keywords: colonialism, modernization, malaria outbreak, Cirebon

\begin{abstract}
Abstrak
Tulisan ini dimaksudkan untuk menganalisis proses modernisasi kota dan bencana wabah malaria di zaman kolonial. Penekanan pada modernisasi di kota kolonial didasarkan pada beberapa dokumen pemerintah Hindia Belanda tentang pembentukan kota-kota di Jawa yang memprioritaskan pembangunan infrastruktur untuk kebutuhan perekonomian, yang kemudian memicu munculnya wabah malaria, terutama di daerah pesisir dan perkebunan. Program modernisasi berbasis industrialisasi ekonomi itu sangat memengaruhi lajunya perekonomian masyarakat, seperti terhadap aktivitas para buruh, pedagang, pegawai kantoran, dan tenaga kesehatan. Dalam proses pembangunan kota, misalnya, wabah malaria menyebar kepada mayarakat yang ada di dalam dinamika perekonomian tersebut. Atas dasar itu, yang menjadi fokus analisis penelitian ini adalah permasalahan modernisasi dengan kemunculan wabah malaria di salah satu kota kolonial di Jawa. Artikel ini penting ditulis untuk menunjukkan bahwa modernisasi tidak selamanya menghasilkan produk budaya yang berdampak positif, tetapi terdapat dampak negatif, yaitu kemunculan wabah malaria yang selalu menjadi persoalan lingkungan dan kesehatan masyarakat.
\end{abstract}

Kata kunci: modernisasi, wabah malaria, Cirebon

\footnotetext{
${ }^{1}$ Artikel ini sudah dipresentasikan pada Seminar Nasional Arkeologi tahun 2020 "Petaka dalam kehidupan manusia” di Hotel Aston Bandung, 18-20 November 2020
} 


\section{PENDAHULUAN}

Indonesia pada masa kolonialisme Belanda pernah mengalami bencana wabah penyakit yang disebabkan oleh berbagai faktor, terutama faktor lingkungan. Pada masa pemerintahan Hindia Belanda gencar dilakukan program modernisasi kota dalam rangka pembentukan kota-kota kolonial berdasarkan konsep budaya Eropa. Berbagai infrastruktur dibangun untuk memenuhi kebutuhan penduduk yang tinggal di kota itu, terutama golongan Eropa. Terdapat beberapa bidang yang menjadi fokus modernisasi di kota-kota di Jawa pada saat itu, di antaranya bidang perekonomian, yang bertujuan untuk meningkatkan hasil perekonomian melalui industrialisasi demi meraih sebanyak-banyak keuntungan bagi negara Belanda. Pada bidang ini, pemerintah membangun berbagai infrastruktur, seperti pelabuhan, jalan raya, jalan kereta api, pabrik-pabrik, perkantoran, saluran air, pasar, dan rumah sakit.

Di bidang kesehatan, Gubernur Jenderal H.W. Daendels (1808--1811) telah berwacana membentuk Dinas Kesehatan Sipil (Burgelijk Geneeskundige DienstBGD) pada tahun 1809. Namun, yang berdiri terlebih dahulu adalah Dinas Kesehatan Militer (Militaire Geneeskundige Dienst-MGD) dengan tujuan memfokuskan terlebih dahulu pada pelayanan kesehatan para anggota militer Belanda yang ada di Jawa dan tentara Belanda asal pribumi. Sementara itu, BGD direalisasikan pada tahun 1820. Pemerintah lebih memfokuskan pada MGD dengan alasan untuk mendapatkan dukungan politik dari para militer perang selama Belanda berkuasa di tanah jajahannya. Adapun BGD menjadi fokus kedua dengan alasan melindungi kesehatan lingkungan kota yang menjadi tempat tinggal para penduduk Eropa. Melalui BGD, pemerintah dapat melayani kesehatan masyarakat sipil di kota dan lingkungan daerah-daerah sekitarnya. Untuk kebutuhan kedua lembaga itu, pemerintah mendatangkan para dokter Eropa. Mereka ditugaskan untuk melayani kesehatan para militer, masyarakat sipil, kesehatan lingkungan kota, dan menganalisis berbagai penyakit yang muncul, terutama kategori penyakit iklim tropis, seperti malaria (Boomgard et al., 1996).

Sebelum abad ke-20, penanganan masalah kesehatan itu belum banyak dilaporkan oleh pejabat-pejabat pemerintah. Menurut van Heteren (Boomgard et al., 1996), hingga memasuki abad ke-20 tidak ada yang membuat laporan tentang pelayanan kesehatan di Jawa. Beberapa laporan hanya sebatas menyampaikan informasi wabah penyakit, tanpa menyertakan langkah-langkah penanganannya. Hal ini dapat dipahami ketika dalam beberapa dokumen pemerintah dan surat kabar yang terbit di abad ke-19 menyatakan bahwa informasi terkait tema kesehatan lebih banyak membahas wabah penyakit di beberapa daerah. Fenomena wabah saat itu adalah sebagai bencana alam yang berdampak menjadi wabah sosial yang mengancam kenyamanan pemerintah Hindia Belanda atas status quo-nya dan mengancam perekonomian karena banyak tenaga kerja yang meninggal. Pada saat 
itu pemerintah lebih memahami penyakit malaria sebagai jenis penyakit yang sangat berbeda dengan penyakit yang ada di negeri asalnya di Eropa. Dampak dari ketiadaan informasi tentang penanganan wabah penyakit itu berakibat pada upaya pemerintah dan kalangan peneliti melakukan try and error atau uji coba terhadap cara mengatasi wabah di daerah jajahan Belanda. Tindakan itu dilakukan dengan cara penelitian, baik terhadap bibit penyakit maupun lingkungan tempat berjangkitnya wabah. Tujuannya adalah untuk menemukan jenis obat yang tepat dan untuk jenis pelayanannya kepada masyarakat.

Baru pada awal abad ke-20, jenis pelayanan kesehatan mulai dilaporkan oleh para residen dan peneliti. Seperti laporan tentang pembangunan rumah sakit berikut pengiriman para dokter dari Eropa, propaganda kebersihan, pembersihan lingkungan kotor, dan pembagian obat-obatan serta vaksin. Demikian juga pencatatan informasi kebijakan kesehatan dan jenis wabah penyakit menjadi awal berita di beberapa media massa, baik milik Eropa maupun pribumi. Laporan-laporan bidang kesehatan yang dibuat oleh para peneliti ataupun para residen selalu dihubungkan dengan dinamika perekonomian yang memiliki keterkaitan dengan pendanaan kesehatan masyarakat untuk tiap-tiap kota.

Dalam laporan-laporan tersebut, berbagai informasi wabah malaria menjadi fokus berita saat itu. Pemerintah menganggap wabah malaria sebagai ancaman serius. Begitu juga masyarakat, menganggap wabah malaria sebagai ancaman kehidupannya. Pemerintah berupaya memberantas wabah malaria itu dengan berbagai cara, seperti pemasangan riol, pembersihan kolam, pembagian pil kina, dan penelitian.

Di Cirebon, wabah malaria menyerang para pekerja proyek pembangunan terutama mereka yang tinggal di lingkungan proyek, di tempat kumuh, dan di tepi pantai. BGD pun memfokuskan perhatiannya untuk pemberantasan wabah malaria dengan memperhatikan kebutuhan kesehatan lingkungan kota dan masyarakatnya (Bahauddin, 2000b). Lingkungan pembangunan jalan raya dan jalan kereta api yang menghubungkan daerah perkebunan, yaitu Sindanglaut dengan pelabuhan dan pusat pemerintahan menjadi fokus perhatian pembersihan wabah karena disinyalir para peneliti sebagai titik awal terjangkitnya bibit malaria. Nyamuk anopheles dan ludhowik yang menjadi bibit malaria sangat menyukai lingkungan kotor di pantai dan di tumpukan tanah. Di tahun 1930-an, lingkungan di Cirebon masih banyak yang kumuh dan kotor. Kerja sama pemerintah kota dengan BGD dalam menangani lingkungan kota dan wabah malaria terus dilakukan sekalipun selalu dibenturkan dengan diskusi kekurangan dana di tingkat kota. Kondisi ini bahkan menjadi sorotan berbagai media massa dan peneliti dalam mengkritik pemerintah perihal kesehatan lingkungan dan masyarakat. Namun, pemerintah tidak menerima berbagai kritikan itu. Wabah malaria saat itu telah merenggut banyak korban, baik dari kalangan buruh perkebunan, buruh pelabuhan, maupun buruh bangunan. Penyakit malaria mewabah di Cirebon mulai dari wilayah pantai ke pedalaman. 
Artikel ini akan menjelaskan peristiwa bencana wabah malaria yang terjadi di Cirebon di tahun 1930-an. Pemerintah menjadikan Cirebon bagian dari program modernisasi kota karena wilayah ini memiliki daerah-daerah perkebunan tebu dan pelabuhan aktif yang menghubungkan Batavia-Cirebon-Semarang. Daya tarik pemerintah dan para pengusaha swasta atas daerah Cirebon, selain kedua faktor lingkungan perkebunan dan pelabuhan, adalah juga karena memiliki daerah penyangga pelabuhan yang sejuk dan subur, yaitu Kuningan dan Majalengka untuk dijadikan tujuan wisata dan misi zending.

Pada tahun 1930-an, setelah jalan raya yang menghubungkan ke wilayahwilayah pedalaman dijadikan lalu lintas distribusi komoditas dagang dan aktivitas lainnya, kontak sosial semakin ramai dan menjadikan kondisi jalan raya rusak. Jalan yang menghubungkan ke Majalengka dan Kuningan dilalui dengan moda transportasi pedati pengangkut sayuran dan tebu. Namun, pengguna sering mengalami kesulitan karena jalan tersebut rusak akibat banjir dan adanya penggalian tanah. Adapun jalan yang menghubungkan perkebunan tebu Sindanglaut ke Pelabuhan dilalui dengan alat transportasi kereta api. Kondisi lalu lintas ini pun terganggu dengan tumpukan puing dan tanah galian perbaikan jalan rel kereta api. Di wilayah-wilayah tersebut sering terjadi banjir saat musim hujan tiba. Sisa pembangunan jalan raya masih berserakan di tempat umum dan tumpukan puing bangunan memperparah kondisi lingkungan saat itu. Kondisi yang seperti itu mengulang bencana wabah malaria yang pernah terjadi pada tahun-tahun sebelumnya. Wabah malaria pada tahun 1930-an dipandang sangat parah dan terjadi di berbagai daerah di Cirebon, seperti di sekitar pantai, di pemukiman pinggiran kota, dan di perkebunan.

Fernando (2010) sedikit mengulas wabah malaria akibat padatnya aktivitas perekonomian di kota Cirebon padamasa modernisasi. Menurutnya, faktor demografi yang meningkat akibat dinamika ekonomi di kota justru berujung pada kelaparan dan kemiskinan sehingga masyarakat rentan terhadap wabah penyakit. Kasus itu terjadi karena pemerintah mengubah sistem kerja, para pekerja yang datang ke kota adalah yang kehilangan lahan tanahnya karena disewa oleh para pengusaha atas izin pemerintah. Sementara itu, kedatangannya ke kota tidak memberi jaminan untuk mencukupi kebutuhan hidupnya. Kondisi itu membuat masyarakat rentan terhadap penyakit dan kurang gizi. Karya Fernando menjadi sumbangan yang berarti dalam penelitian ini, terutama dalam melihat dampak urbanisasi di kota (Fernando, 2010).

Kepadatan penduduk dan kondisi rentan penyakit pada masyarakat di kota Cirebon telah mempercepat persebaran penyakit malaria. Pekerja pun tidak mampu berobat dengan kondisi miskin seperti itu. Selain itu, para dokter juga enggan memeriksa pasien yang tidak mampu bayar. Pasien malaria saat itu banyak yang meninggal. Jan Breman mengulas kondisi tersebut karena adanya lonjakan jumlah penduduk di Cirebon pada awal abad ke-20, terutama para pekerja bangunan dan 
perkebunan. Kondisi tersebut yang mengawali kemiskinan masyarakat pribumi dan meningkatkan persebaran wabah malaria (Breman, 1986). Jelas bahwa korelasi antara program modernisasi dan kemunculan wabah malaria telah menjadi perhatian para ilmuwan selain sejarawan.

Oleh karena itu, yang menjadi fokus permasalahan dan pertanyaan penelitian ini adalah mengapa modernisasi kota di Cirebon menjadi penyebab bencana wabah malaria pada tahun 1930-an?

Artikel ini bertujuan menganalisis hubungan modernisasi kota dengan bencana wabah malaria.

Metode yang digunakan dalam penulisan artikel ini adalah metode sejarah, yang ditempuh melalui empat langkah. Tahap pertama adalah heuristik atau pengumpulan sumber. Tahapan kedua adalah mengkritik sumber untuk mendeteksi keaslian sumber dan kebenaran data yang ada di dalamnya. Tahap ketiga adalah interpretasi atau penafsiran atas data yang diperoleh sebagaimana adanya, untuk memberikan gambaran kenyataan peristiwa yang terjadi di masa lalu. Tahap keempat merupakan tahap akhir penelitian, berupa sintesis, yaitu penyajian sebagai karya sejarah, dalam hal ini karya penelitian dalam bentuk artikel sejarah. Sebagai karya sejarah, peristiwa masa lalu merupakan hal yang nyata. Berger dan Luckmann, sekalipun seorang sosiolog, ketika menggunakan pendekatan fenomenologis dan sejarah (Berger \& Luckman, 2013), beranggapan bahwa peristiwa pada masa lalu dapat dipahami sebagai sebuah kenyataan, baik sebab maupun akibat dari sebuah peristiwa yang terjadi pada masa lalu itu.

\section{HASIL DAN PEMBAHASAN}

\section{Masa Modernisasi di Cirebon yang Memunculkan Wabah Malaria}

Kata modernisasi sering dipahami berasal dari kata modern yang berarti 'terbaru, mutakhir, atau sikap dan cara berpikir yang sesuai dengan tuntutan zaman'. Modernisasi dipahami sebagai suatu proses mengubah dari sistem yang tradisional menjadi lebih maju berdasarkan perkembangan ilmu pengetahuan (Depdikbud, 1991). Proses modernisasi dalam kajian ini lebih kepada upaya pemerintah Hindia Belanda mengubah lingkungan geografis ataupun pola pikir dan budaya masyarakatnya, terutama masyarakat pribumi, yang dipandang tradisional sehingga menjadi lebih maju yang mengikuti budaya Eropa yang diterapkan pemerintah saat itu.

Menurut S. Margana, sebagaimana yang disebutkan dalam buku Nursam (2010) modernisasi kota dapat menjadi pemicu permasalahan baru, di antaranya kemiskinan dan permasalahan pelayanan kesehatan. Permasalahan tersebut menjadi kompleks, bahkan menyertai permasalahan perekonomian sebagai tujuan utama pemerintah. Kemiskinan muncul sebagai permasalahan mendasar masyarakat pribumi ketika mereka tidak dapat lagi menggarap lahan tanah miliknya. 
Kemiskinan juga semakin meningkat di kota ketika beban jumlah individu yang harus diperhatikan pemerintah meningkat pula seiring dengan tingkat urbanisasi. Beban ekonomi ini saling bekelindan dengan beban pelayanan kesehatan yang harus diberikan kepada masyarakat ketika angka morbiditas turut meningkat. Demikian permasalahan-permasalahan yang mucul secara bersamaan pada masa modernisasi awal abad ke-20. Margana, memang tidak mengulas permasalahan wabah penyakit yang timbul akibat modernisasi, tetapi penjelasannya tentang permasalahan kelaparan dan kemiskinan menggambarkan fenomena permasalahan pelayanan kesehatan yang menjadi bagian dari proses modernisasi.

Pemerintah Hindia Belanda yang terlalu asyik dengan peningkatan sektor perekonomian, kemudian melimpahkan tugas dan tanggung jawab bidang kesehatan kepada BGD. Lembaga BGD difungsikan untuk mengawasi kebersihan dan kesehatan di lingkungan kota di bawah pengawasan pemerintah kota (Bahauddin, 2000b).

Ketika Cirebon dijadikan sasaran program modernisasi oleh pemerintah Hindia Belanda (1 April 1906), aktivitas perekonomian di Pelabuhan menjadi semakin ramai dikunjungi para pendatang luar Jawa dan Eropa. Pelabuhan Cirebon menjadi penampung barang-barang komoditas dagang yang digemari pedagang Eropa. Suplai tebu yang banyak dari perkebunan tebu di berbagai daerah pedalaman Cirebon, seperti Sindanglaut dan Majalengka, menambah tingginya pundi-pundi pemerintah. Selain itu, beras yang berkualitas bagus dari Indramayu selalu dikapalkan melalui Pelabuhan Cirebon. Untuk mendukung semua itu, pemerintah kota terus memperbaiki infrastruktur pelabuhan dan jalan penghubung pelabuhanperkebunan.

Program infrastruktur tersebut dilakukan tiga tahap. Tahap pertama di lokasi pantai dan pelabuhan. Tahap kedua di lokasi gudang penampung barang dagangan. Tahap ketiga di lokasi peron. Selanjutnya, perbaikan jalan raya darat dilakukan di tempat yang biasa dilalui pedati dan gerobak tebu dan sayur. Hal ini seperti yang disebutkan oleh Emalia (2020b) bahwa berdasarkan Staatsblad No. 122 yang merupakan koleksi ANRI (Arsip Nasional Republik Indonesia), tentang pembentukan kota-kota di Jawa, pemerintah banyak memfokuskan pembangunan infrastruktur di kota Cirebon, di antaranya jalan raya, rel kereta api, dan jalan-jalan yang menghubungkan ke pedalaman. Selama program pembangunan itu, terjadi tumpukan tanah dan material yang tidak tersimpan dengan baik di sepanjang lokasi pembangunan. Selama program itu pun sering terjadi banjir jika musim hujan tiba dan menyisakan genangan air kotor serta kumuh di lingkungan tersebut.

Para pekerja proyek pembangunan infrastruktur yang direkrut dari kalangan masyarakat pribumi tinggal di sekitar perkebunan dan pelabuhan serta di lokasi pembangunan. Mereka diupah dengan sistem gaji bulanan. Sejak awal modernisasi, penerapan sistem uang untuk upah para pekerja dan transaksi lainnya sudah tidak asing lagi bagi mereka. Pendapatan yang tidak mencukupi hidup bukan juga sebagai 
hal yang baru. Namun, karena mereka perlu bertahan hidup di kota, tawaran kerja kasar dengan upah rendah itu tetap diterimanya. Para pekerja ini yang sering tertimpa bencana banjir dan berbagai dampaknya.

Dinamika modernisasi kota Cirebon sangat dipengaruhi oleh aktivitas perekonomian saat itu. Kondisi tersebut didukung oleh alam Cirebon yang memiliki katersediaan sumber daya alam yang subur yang dapat dimanfaatkan oleh para saudagar asing. Dalam penjelasan Hendro, dinamika modernisasi di kota Cirebon membuat peran perkampungan sebagai tempat-tempat pemukiman masyarakat pribumi menyurut, sementara fungsi jalan dan transpotasinya menjadi lebih penting (Hendro, 2014). Pemerintah membangun infrastruktur, seperti jalan raya dan bangunan-bangunan di kota Cirebon, yang mendukung peningkatan perekonomian pemerintah. Masyarakat pribumi yang menempati lokasi tersebut menjadi terpinggirkan. Mereka dihadapkan dengan berbagai proses modernisasi, tetapi tidak saja karena alasan modal yang dimilikinya, baik modal ekonomi maupun pendidikan yang membuat mereka tidak sejahtera di kota, juga karena kebijakan pemerintah saat itu yang diskriminatif terhadap golongan pribumi. Kelayakan hidup masyarakat pribumi jauh dari yang diterima oleh golongan masyarakat lain, terutama golongan Eropa. Pemerintah memberdayakan masyarakat pribumi kebanyakan pada sektor buruh bangunan, dengan upah yang tidak mencukupi kebutuhan hidupnya.

Pada musim hujan pada tahun 1930--1937 banyak buruh proyek pembangunan jalan raya, pembangunan pelabuhan, dan buruh perkebunan terserang malaria. Pada saat itu, nyamuk aedes aegypti sebagai pembawa bibit penyakit malaria banyak berkembang di sekitar lokasi pembangunan. Nyamuk malaria tumbuh di tempattempat yang menyimpan genangan air, di tumpukan-tumpukan puing bangunan, dan di lokasi sisa penggalian tanah di jalan. Sungai utama yang melintasi daerah pusat kota Cirebon, yaitu sungai Kalibacin menjadi memadat oleh lumpur dan sampah sisa penebangan pohon di bibir sungai. Kondisi ini yang memicu tumbuhnya nyamuk malaria tersebut. Masyarakat yang terdampak nyamuk malaria kebanyakan yang tinggal di sekitar lokasi pembangunan, seperti di Kanggraksan, Harjamukti, Pelabuhan, dan yang menempati lokasi bantaran sungai. Sampai musim kemarau tiba, nyamuk malaria tidak hilang dari lokasi-lokasi itu. Hal ini disebabkan tempattempat yang banyak menyimpan genangan air tidak menjadi perhatian pemerintah ataupun petugas proyek pembangunan untuk segera ditutup atau diperbaiki. Nyamuk malaria kemudian menjadi wabah penyakit yang menyebar ke banyak tempat di kota Cirebon dan perbatasan kota, seperti Kuningan, Majalengka, dan Brebes (Emalia, 2020b).

Daerah-daerah yang dekat dengan program pengembangan kota atau modernisasi kota sangat banyak terdampak wabah malaria, seperti kota Cirebon yang menjadi pusat pemerintahan Gemeente, Cangkol yang dekat dengan Pelabuhan Cirebon, Pelabuhan, Kanggraksan, dan Harjamukti. Setelah itu yang terdampak adalah daerah perkebunan tebu di sekitar Sindanglaut, Waled, dan Ciledug. 
Sementara daerah perbatasan ke Kuningan dan Majalengka mendapatkan dampak wabah malaria tidak sebesar di daerah-daerah perkotaan tadi. Pada tahun 1930-an,

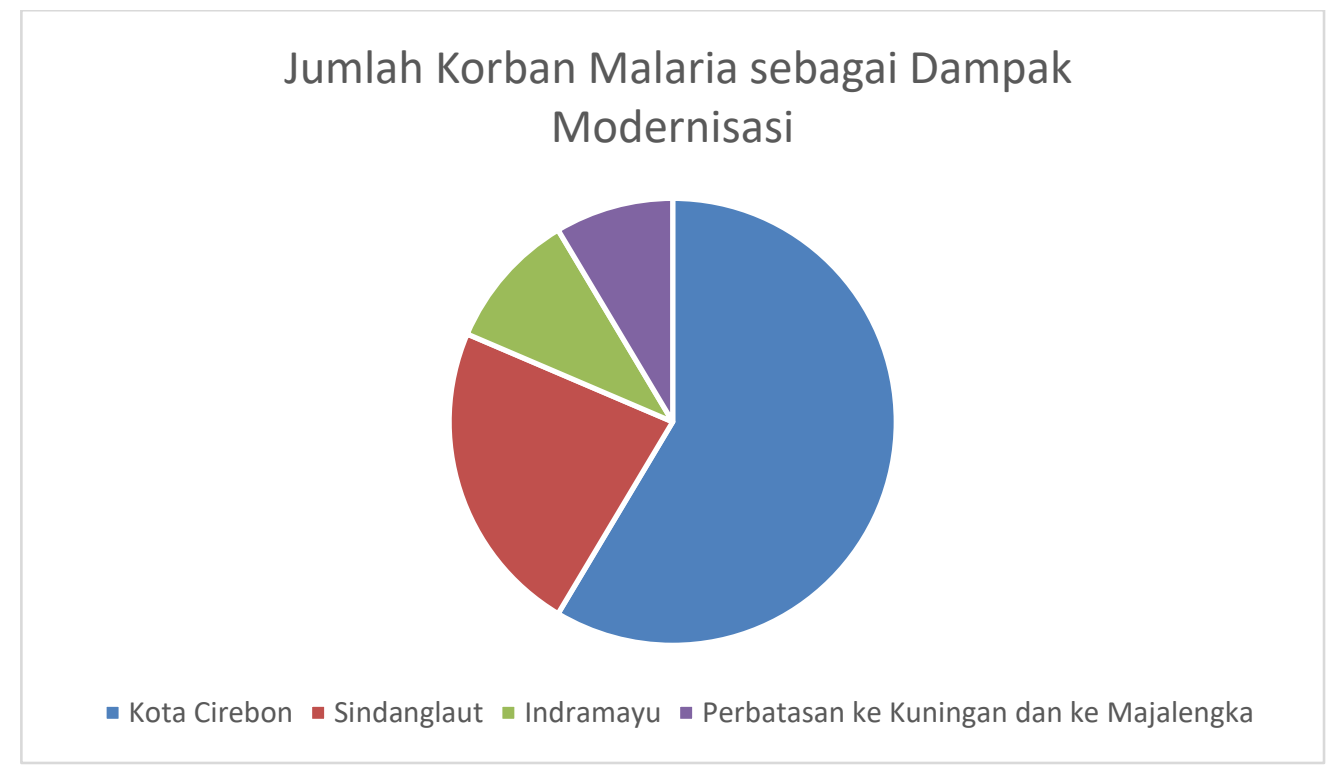

Gambar 1. Grafik Wilayah Korban Malaria di Cirebon, 1930-an (Sumber: diolah dari Emalia, Imas. (2020b). Wabah Penyakit dan Penanganannya di Cirebon 196-1940. Yogyakarta: Ombak).

pusat wabah adalah di kota Cirebon itu sendiri dan menempati angka tertinggi di sepanjang dekade ketiga awal abad ke-20. Jika digambarkan dalam bentuk grafik, hal tersebut kurang lebih dapat dilihat seperti berikut (Gambar 1).

Pada musim wabah malaria awal abad ke-20, para peneliti dan beberapa surat kabar saat itu, seperti De Preanger Bode, Het Nieuws van Den Dag Voor Nederlandsch Indie, dan Bataviaasch Nieuwsblad, sudah ramai menyoal wabah malaria di kota Cirebon. Berita itu pun disertai pandangan-pandangannya terhadap sikap pemerintah dalam menghadapi bencana itu. Sebagai contoh dari berita surat kabar De Preanger Bode disebutkan bahwa terdapat kebingungan yang ditampilkan pemerintah kota Cirebon ketika menghadapi wabah penyakit malaria itu. Sejak tahun 1917, surat kabar ini menyebutkan bahwa sejak awal modernisasi kota Cirebon, yaitu sejak 1906, pemerintah memandang penyakit malaria itu sebagai penyakit yang aneh yang tiba-tiba mematikan banyak penduduk di wilayah kekuasaannya. Pemerintah kebingungan dengan penyakit malaria yang terus menyebar pada tahun-tahun itu yang disebutnya juga sebagai penyakit tropis karena tidak ada di Eropa. Ada kemungkinan sikap tersebut sebagai kehati-hatiannya untuk menentukan kebijakan kesehatan atau hanya menunggu hasil penelitian para peneliti penyakit dan para dokter. Namun, kemudian surat kabar ini pun mengkritik pandangan pemerintah, bahwa sikap kebingungan itu adalah sebagai sebuah alasan belaka untuk lepas tangan dari pembiayaan penanganan wabah penyakit. Pemerintah 
terlalu banyak mengalokasikan dana pembangunan jalan raya dan pelabuhan, tetapi tidak seimbang dengan alokasi dana untuk kesehatan (De Preanger Bode, 1917a).

Para peneliti penyakit mengategorikan penyakit malaria sebagai penyakit masyarakat karena banyak menyerang masyarakat secara merata. Namun, sangat disayangkan pemerintah bersikap apatis. Padahal, semua golongan masyarakat menjadi korban dari bencana wabah penyakit ini. Dalam berita surat kabar De Preanger Bode, 7 Mei 1917, sudah dijelaskan bahwa penyakit malaria sudah ada sejak abad ke-19 sehingga sikap kebingungan pemerintah dalam mengatasi wabah malaria merupakan sikap apatis. Seperti petikan dari surat kabar tersebut sebagai berikut.

"Sebenarnya penelitian tentang malaria telah dilakukan di awal modernisasi. J.J. van Lonkhuizen memprotes wali kota Cirebon, R.A.A Schotman. Dia tidak memperhatikan lingkungan kota sehingga banyak pekerja di kota meninggal karena malaria. Wali kota itu tidak melihat kebutuhan para pekerja tapi lebih melihat kebutuhannya sendiri”.

“... pada akhirnya...akibat malaria itu ...melumpuhkan perekonomian. Dampak dari lingkungan kota yang kumuh, wabah malaria menyebar ke manamana, selain juga karena banyaknya penyakit kulit, seperti kudis, cacar (patek), ..." (De Preanger Bode, 1917b).

Informasi-informasi dari surat kabar tersebut menunjukkan bahwa kemunculan wabah malaria itu sebagai bencana sosial yang sesungguhnya dibuat oleh tangan manusia sendiri. Wabah malaria muncul karena dampak dari kelalaian pemerintah dalam memperhatikan kesehatan lingkungan dan masyarakatnya sendiri. Sejak awal modernisasi, pembangunan infrastruktur di kota Cirebon tidak berorientasi kesehatan lingkungan. Pemerintah membiarkan genangan-genangan air dalam waktu yang lama, membiarkan tumpukan puing-puing sisa bangunan di berbagai tempat, membiarkan tumpukan galian tanah di sepanjang jalan kota dan jalan menuju ke perbatasan kota, membuang sampah hutan ke sungai yang mengalir ke kota, serta melokalisasi para buruh di tempat yang kumuh dan tidak layak. Persebaran wabah malaria bermula dari lingkungan ini dan dari para korban. Korban malaria kemudian melumpuhkan perekonomian karena kebanyakan di antara mereka adalah para buruh bangunan dan perkebunan.

Sikap pemerintah lainnya pada masa wabah malaria saat itu adalah keengganannya mengurus pasien asal pribumi dan tidak memberikan dana pengobatan, mereka harus tetap membayar pengobatannya di rumah sakit. Sikap itu pun berimbas kepada para dokter Eropa, yaitu mendiskreditkan pasien pribumi karena tidak mampu membayar biaya berobat. Bencana kematian akibat malaria akhirnya menjadi tidak terelakkan lagi. Kondisi seperti itu, yang menurut Spiegel dan juga dalam penjelasan Basundoro, bahwa ruang kota seperti itu telah menciptakan arena perebutan hak sehat antara pemerintah, penduduk asing, dan 
pribumi. Bagi mereka yang tidak bernasib baik dalam mendapatkan pelayanan kesehatan, mereka berujung dengan kematian (Basundoro, 2018;) (Spiegel, 2005).

Pada masa Residen Cirebon, C.J.A.L.F Hiljee, 3 Juni 1930, wabah malaria terjadi saat pembangunan sarana transportasi, khususnya jalan raya di kota. Namun, Hiljee hanya mencatat tentang pelayanan kesehatan oleh pemerintah kota yang difokuskan kepada penduduk Eropa, tidak mencatat tentang pelayanan kesehatan oleh masyarakat pribumi (pengobatan tradisional). Saat itu pemerintah sangat memperhatikan kesehatan golongan Eropa dan jumlah morbiditasnya. Alasannya, tentu karena kekhawatiran atas berkurangnya jumlah penduduk golongan Eropa yang akan melemahkan status politiknya. Namun, secara tidak sadar, sikap itu justru telah menjadi ancaman besar bagi keruntuhan perekonomiannya.

Dalam catatan Emalia, sebagaimana yang dikutip dalam Republika tentang keterkaitan wabah malaria dan perekonomian di Cirebon pada masa modernisasi, dijelaskan bahwa seiring dengan proses modernisasi kota, para buruh di berbagai proyek pembangunan telah menjadi sasaran utama bibit malaria. Modernisasi di awal abad ke-20 telah menuai bencana wabah malaria pada masyarakat Cirebon dan sekitarnya. Proses modernisasi telah membuat wilayah pesisir, pusat kota, perkebunan, dan jalan yang menghubungkan ke pedalaman menjadi kotor dan kumuh, serta bibit malaria pertama kali menyerang adalah kepada para pekerja dan penghuni permukiman di lingkungan tersebut (Emalia, 2020c).

Maka dalam hal ini, pelayanan kesehatan dan pemberantasan wabah malaria di awal abad ke-20 dapat dikatakan gagal dan tidak sebanding dengan program modernisasi kota. Laporan residen Cirebon pun mengindikasikan kegagalannya dalam menangani bencana malaria pada tahun 193-0an, yaitu dari adanya sejumlah besar buruh yang meninggal akibat serangan wabah malaria.

\section{Wabah Malaria dan Penanganannya}

Jika kita melihat laporan residen Cirebon Hiljee, sesungguhnya paradoks pembangunan banyak jenisnya, di antaranya adalah kelaparan, kemiskinan, korupsi, dan wabah penyakit. Hal seperti itu sangat relevan dengan pandangan Napitupulu pada masa sekarang, bahwa paradoks pembangunan dapat terjadi selama proses pembangunan itu dijalankan, yaitu munculnya kemiskinan, wabah penyakit, korupsi, prostitusi, ketegangan-ketegangan sosial, dan sebagainya. Tentunya hal itu terjadi jika pembangunan tidak berorientasi kesehatan lingkungan (Napitupulu, 2020).

Kebijakan pemerintah kolonial saat itu, tentunya tidak hanya untuk satu aspek, tetapi beberapa aspek yang sangat mendukung bagi keberlangsungan perekonomian dan status quo-nya. Kebijakan kesehatan pemerintah kolonial Belanda, seperti yang diulas oleh (Bahauddin, 2000a) (Bahauddin, 2000b), bahwa perubahan fungsi kotakota di Jawa dalam rangkaian modernisasi padaabad ke-20 melibatkan pembenahan pelayanan kesehatan. Kebijakan ini, sebagai implementasi dari politik etis sekalipun, tidak terlalu ditekankan. Perhatian pemerintah terhadap kesehatan masyarakat 
dibuktikan dengan pembangunan-pembangunan rumah sakit, pelatihan dokter Djawa, dan bidan desa yang terus dilakukan di kota-kota di Jawa. Furnivall (Belshaw \& Furnivall, 1956; Trager, 1957) menjelaskan hal itu bahwa pemerintah kolonial Belanda memperhatikan kesehatan masyarakat, khususnya terkait penyakit menular dan mematikan, seperti cacar, kolera, dan malaria yang terjadi di hampir semua wilayah di Pulau Jawa. Penjelasan Furnivall itu mengindikasikan adanya kesalahan dalam proses modernisasi kota sekalipun terdapat kebijakan kesehatan yang dibuat oleh pemerintah Hindia Belanda. Kebijakan kesehatan merupakan keniscayaan yang berhak diterima seluruh golongan masyarakat. Namun, sistem kesehatan (health sistem) yang banyak keterkaitannya dengan berbagai aspek kehidupan kurang diupayakan.

Inilah yang kemudian menyimpukan bahwa kehadiran modernisasi kota telah menyulap lingkungan kota menjadi lingkungan sarang penyakit. Modernisasi yang dijalankan pemerintah tidak sesuai dengan konsep awal yang bertujuan membenahi pemukiman penduduk kota yang baik, rapi, indah, dan sehat, yang terjadi sebaliknya. Hal itu disebabkan dalam ralitasnya kebijakan wajib sewa bangunan, kewajiban bayar berobat, dan kewajiban kerja sepenuh hari (sekalipun kondisi sakit) menuai bencana kemiskinan, kelaparan yang panjang, dan wabah malaria yang mematikan.

Dalam analisis Hendrick L. Blum, keterkaitan antara lingkungan dan perilaku sosial, seperti yang disebutkan sebelumnya, dapat menjadi faktor utama derajat kesehatan (health seeking behavior). Sikap masyarakat yang tidak mampu beradaptasi dengan lingkungan dan budaya barunya itu semestinya menjadi tanggung jawab pemerintah (Hingson, 1981).

Dalam surat kabar Bataviaasch Nieuwsblad (24 Mei 1930) diberitakan bahwa sebagai berikut.

"Pembangunan sangat mempengaruhi kondisi kesehatan lingkungan dan kondisi kesehatan para pekerja, tapi jauh dari perhatian pemerintah".

"...akibat rumah di pinggiran kota yang seperti gubuk, pada ... awal tahun 1930 menyebabkan wabah malaria menyerang penduduk. Penyakit malaria mengancam penduduk di lingkungan rumah gubuk ini. Malaria menyebar ke Kuningan terutama onderdistrik Kadugede dan Cilimus, lalu ke Majalengka di onderdistrik Talaga" (Bataviasch Nieuwsblad, 1930).

Wabah malaria sepanjang tahun 1930-an itu terus terjadi. Surat kabar De Indische Courant yang terbit 2 November 1938 memberitakan bahwa penangann pemerintah atas wabah malaria sangat minim sehingga wabah malaria tidak pernah hilang. Bahkan, pemerintah lalai terhadap wabah malaria itu. Berikut berita surat kabar tersebut.

"Penyakit malaria di tahun 1937 menyebar di masyarakat yang disebabkan banyaknya lokasi genangan air sisa pembangunan yang dibiarkan tanpa perhatian, ironinya malaria menyebar di pusat kota Cirebon yaitu Kanggraksan 
dan Harjamukti. Pemerintah lalai dalam menangani penyakit malaria. Malaria menyebar dari pantai ke pedalaman” (De Indisch Courant, 1938).

Namun, dalam laporan pemerintah terdapat keterangan adanya pelayanan terhadap wabah malaria bagi pasien yang berkunjung ke rumah sakit. Seperti pada tahun 1932, dalam catatan laporan itu dituliskan data jumlah kunjungan pasien ke Rumah Sakit Oranje Cirebon (Tabel 1), sekitar pasien 1.618 orang (Emalia, 2020a; Supratman, 2013). Berikut contoh tabel data kunjungan pasien ke Rumah Sakit Oranje Cirebon di tahun 1932.

Tabel 1. Data Kunjungan Pasien di Rumah Sakit Oranje Cirebon, Tahun 1932, 6\% Meninggal Akibat Malaria

\begin{tabular}{cc}
\hline Bulan & Jumlah \\
\hline Januari & 151 \\
Pebruari & 140 \\
Maret & 157 \\
April & 144 \\
Mei & 134 \\
Juni & 135 \\
Juli & 130 \\
Agustus & 101 \\
September & 92 \\
Oktober & 82 \\
November & 77 \\
Desember & 84 \\
\hline
\end{tabular}

Sumber: Verslag der Gemeente Cheribon over 1932, lihat juga Frial Ramadhan Supratman. 2013. 'Menuju Kota Sehat: Usaha Meningkatkan Kualitas Kesehatan di Kota Cirebon pada Masa Kolonial 1915-1942”. Skripsi. Depok: FIB UI.

Surat kabar Koemandang Masjarakat (Koemandang Masjarakat, 1940) tidak banyak menyebutkan jumlah kematian penduduk akibat penyakit malaria pada tahun 1930-an. Surat kabar ini hanya menyebutkan kondisi beberapa daerah di keresidenan Cirebon yang sangat parah karena wabah malaria yang banyak melanda para pekerja atau buruh perkebunan dan para nelayan di Pelabuhan (Tabel 2). Berita itu pun tidak disertai penyebutan jumlah yang pasti dari penderita penyakit malaria dan jumlah kematian akibatnya. Sebagian penjelasan dalam surat kabar itu disebutkan adanya tindakan pemerintah dalam menangani pasien malaria, yaitu dengan memberikan pil kina kepada pasien dan keluarganya, tetapi pembagiannya tidak merata karena masih banyak penderita malaria yang tidak mendapatkannya. Pembagian pil kina dibantu oleh mantri kesehatan atau tenaga kesehatan pembantu para dokter.

Tabel 2. Jumlah Kematian Akibat Penyakit Malaria pada Tahun 1930-a Berdasarkan Berita Surat Kabar Koemandang Masjarakat Tahun 1940

\begin{tabular}{clcl}
\hline Tahun & \multicolumn{1}{c}{ Tempat } & Jumlah & \multicolumn{1}{c}{ Keterangan } \\
\hline 1932 & Kota Cirebon & 38 & \\
& Ciledug & 2 & $\begin{array}{l}\text { Sebagian penjelasan menyebutkan masih banyak korban } \\
\text { malaria }\end{array}$ \\
& Waled & 2 & \\
\multirow{2}{*}{1937} & Pasaleman & 1 & Tidak disebutkan jumlah, hanya dijelaskan kondisinya
\end{tabular}




\begin{tabular}{clrl}
\hline \multirow{2}{*}{1939} & Karangampel & sangat parah dan banyak yang meninggal akibat malaria \\
& Cangkol & 4 & \\
1940 & Harjamukti & 15 & \\
& Kota Cirebon & 1 & $\begin{array}{l}\text { Sebagian penjelasan menyebutkan masih banyak korban } \\
\text { malaria }\end{array}$ \\
\hline Sumber: Koemandang Masjarakat, 1940. &
\end{tabular}

Menurut Fernando, sejak awal tahun 1930 hampir seluruh masyarakat Cirebon mengalami stamina buruk, kurang gizi, dan kelaparan yang hebat sehingga rentan terserang penyakit. Pertumbuhan nyamuk anopheles dan aedes aegypti di beberapa titik kota akibat banyak genangan air saat musim hujan telah memperparah kondisi kesehatan para pekerja di kota. Wabah malaria di daerah ini lebih sebagai imbas dari modernisasi (Fernando, 2010). Masyarakat pribumi di kota mengalami nasib buruk yang berlapis. Setelah terenggut hak hidupnya di lingkungan kota karena sistem diskriminasi sosial, mereka juga mengalami diskriminasi dalam mendapatkan pelayanan kesehatan.

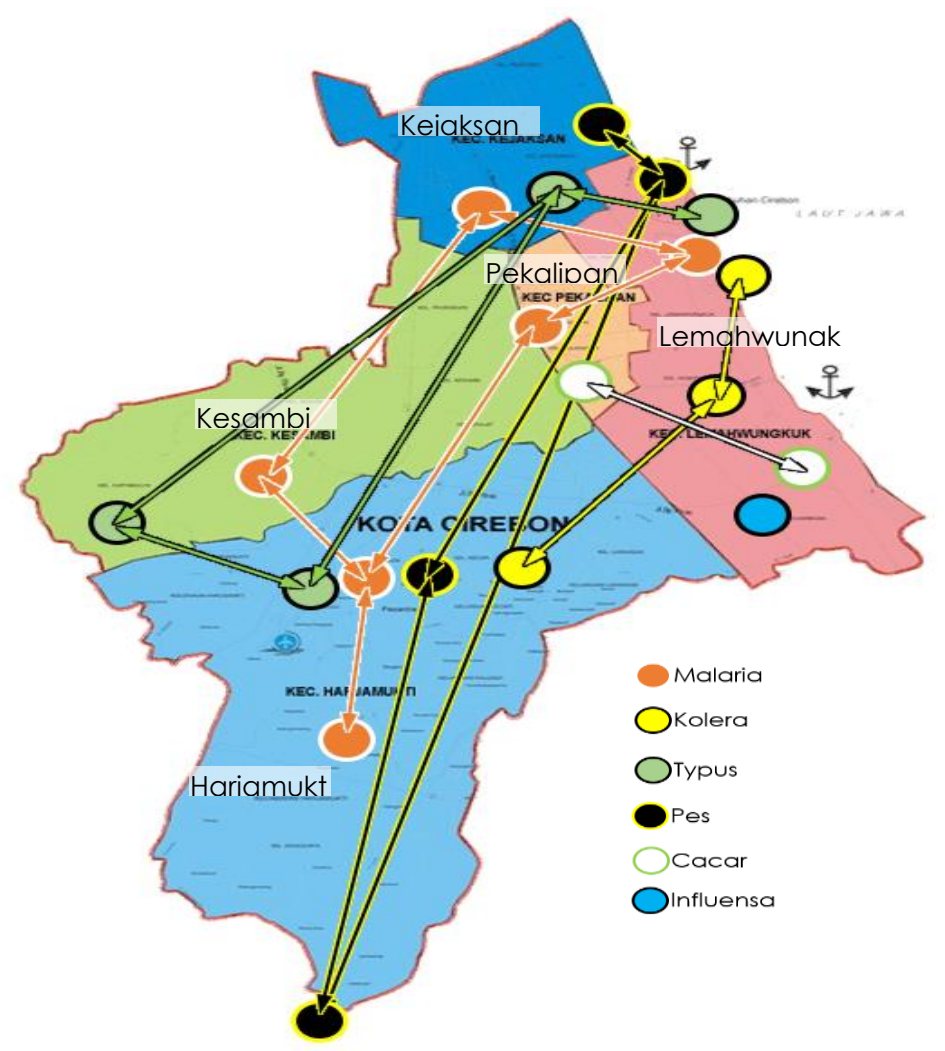

Gambar 2. Peta Persebaran Berbagai Wabah Penyakit di Kota Cirebon, 1906-1940. (Sumber: Peta dibuat oleh Epa Elfitriadi (2019) berdasarkan sumber-sumber kolonial dan surat kabar-surat kabar sezaman yang menjelaskan lokasi persebaran berbagai wabah penyakit).

Dalam menanggapi berbagai kritikan dari berbagai media massa saat itu, pemerintah kemudian berupaya menambah jumlah dokter dan mantri untuk mengobati pasien malaria. Pemerintah juga meningkatkan penanganan banjir dengan melanjutkan proyek perbaikan sungai dan jalan raya, yaitu memasang riol di 
beberapa sungai di kota. Sayangnya, pemerintah tidak membersihkan puing-puing dan tumpukan tanah galian di sepanjang jalan kota dan yang menghubungkannya dengan daerah pedalaman. Tumpukan tanah itu menyebarkan bau busuk di sekitar kota. Akibatnya, di musim penghujan tahun 1937, banjir terjadi lagi, bahkan lebih besar daripada tahun-tahun sebelumnya. Surat kabar Het Nieuws van den dag voor Nederlandsch Indie menyebutkan bahwa banjir pada tahun itu merupakan bencana banjir terbesar di kota Cirebon. Sampah banjir terutama berasal dari puing bangunan jalan raya, pembangunan rel kereta api, dan sampah penebangan hutan. Wabah malaria kembali muncul dan menelan banyak korban. Surat kabar Het Nieuws van den dag voor Nederlandsch Indie itu memberitakan dampak banjir pada tahun 1937 adalah penyakit malaria yang mewabah hingga ke Indramayu, Eretan, dan Karangampel. Berita tersebut adalah sebagai berikut.

"Sisa-sisa puing bangunan dan tanah galian jalan di bibir sungai dan bibir jalan menjadi penyebab penyakit malaria yang menyebar dari kota Cirebon ke Indramayu, Eretan, dan Karangampel" (Het Nieuws van Der Dag Voor Netherlandsch Indie, 1937).

Dokter G.J. Overbeek dan dr. Ave Lallemant, peneliti malaria di Cirebon, sebagaimana yang diberitakan dalam surat kabar itu, berasumsi bahwa bencana banjir dan malaria itu disebabkan karena buruknya sistem infrastruktur dan pelayanan kesehatan. Surat kabar Het Nieuws van Den Dag Voor Nederlandsch Indie (11 Februari 1938) mengutip pendapat kedua dokter tersebut bahwa "tumpukan tanah got dan aliran air sungai akibat banjir itu memudahkan tumbuhnya nyamuk ludlowik dan anopheles. Itulah sebabnya penularan penyakit malaria menjangkau wilayah yang jauh dari pusat wabah, seperti Indramayu, Kuningan dan Majalengka karena mengikuti aliran air (Het Nieuws van Der Dag Voor Netherlandsch Indie, 1938).

Para pejabat pemerintah mulai dari tingkat desa hingga keresidenan yang bekerja sama dengan para dokter Djawa gencar melakukan propaganda kebersihan lingkungan, baik untuk lingkungan pantai maupun pedalaman serta pembagian pil kina dan obat-obatan lainnya (Gambar 3) (Jaelani, 2013) dan penyemprotan dengan minyak tanah. Upaya itu menunjukkan hasil pada tahun 1939. Pemerintah pun baru menyadari kehilangan sejumlah besar para pekerja perkebunan tebu dan pekerja proyek pembangunan akibat malaria sehingga memengaruhi pemasukan keuangannya (Bataviasch Nieuwsblad, 1939). Propaganda kebersihan dimaksudkan untuk mengedukasi masyarakat tentang pentingnya kesehatan lingkungan dan perilaku hidup sehat (Nugroho et al., 2012). 


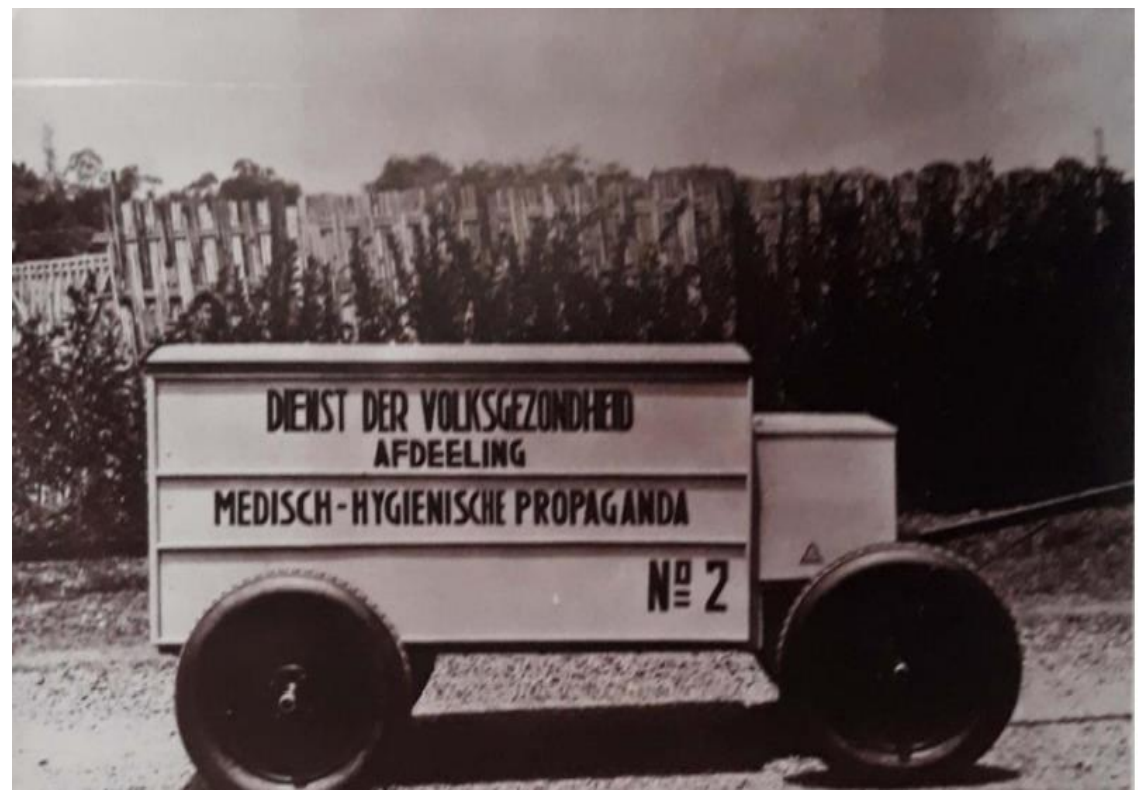

Gambar 3. Gerobak Obat yang Dibawa Para Dokter Djawa Saat Propaganda Kesehatan dan Pembagian Obat (Sumber: ANRI, KIT Jawa Barat, No. 114/44)

Peter Boomgard memberi perhatian tersendiri terhadap kebijakan pemerintah dalam penanganan wabah malaria pada awal abad ke-20. Dalam artikel The Development of Colonial Health Care in Java: an Exploratory Introduction yang terbit pada jurnal Bijdragen tot de Taal-, Land- en Volkenkunde di Leiden, dia melihat adanya kemajuan penanganan wabah malaria. Adanya penurunan jumlah korban wabah penyakit di pertengahan abad ke-20 mengindikasikan peningkatan kualitas penanganan wabah penyakit untuk pasien. Adanya pemberian pelayanan kesehatan oleh para dokter di lembaga-lembaga kesehatan yang dibangun saat itu dan adanya propaganda kebersihan yang melibatkan dokter dan pejabat pemerintah adalah sebagai penanda kemajuan tindakan atau kebijakan pemerintah dalam menangani penyakit dan upayanya dalam memutus persebaran wabah penyakit. Terlepas dari masih adanya kasus wabah malaria saat itu (Boomgard, 1993).

Pelayanan kesehatan oleh pemerintah maupun swasta diberikan melalui berbagai lembaga kesehatan seperti poliklinik, rumah sakit, rumah bersalin, dan sebagainya. Fungsi lembaga-lembaga kesehatan masih berjalan hingga diadakan revitalisasi oleh pemerintahan Republik Indonesia disebabkan berbagai alasan, termasuk kondisi fisik. Seperti yang terjadi pada bangunan klinik swasta yang ada di perkebunan tebu Sindanglaut yang kini tidak layak untuk difungsikan. Sebagai contoh, klinik swasta di sekitar perkebunan tebu dan pabrik gula Sindanglaut kini tinggal sisa bangunannya karena sudah hancur. Pemerintah memindahkan lokasi klinik dengan bangunan yang baru ke arah barat bangunan lama ini. Berikut gambar sisa-sisa bangunan klinik swasta perkebunan sebagai layanan kesehatan bagi para buruh perkebunan. 


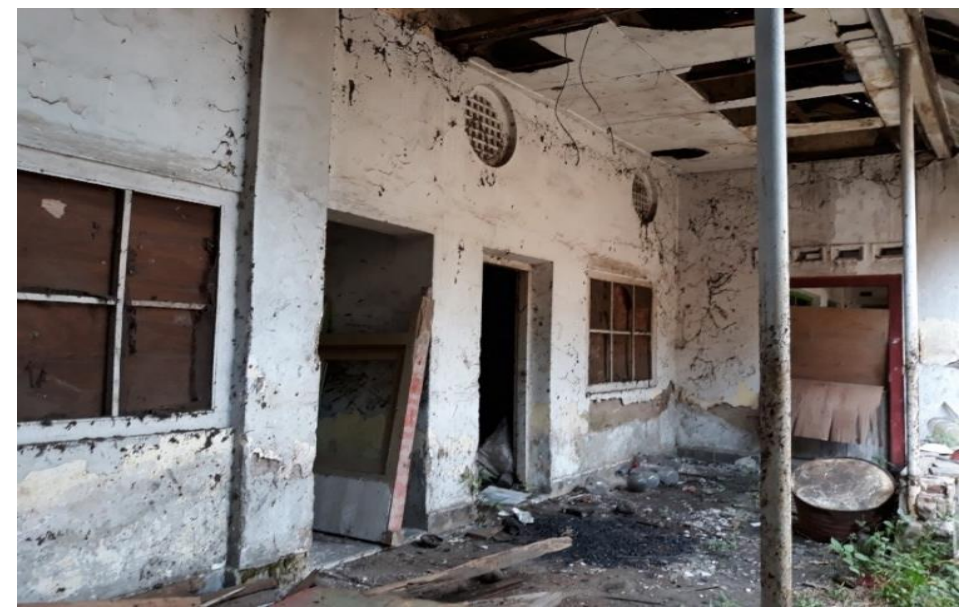

Gambar 4. Sisa Bangunan Klinik Swasta di Lingkungan Perkebunan Tebu dan Pabrik Gula Sindanglaut, 2017 (Sumber: Dokumen Pribadi, 15 Mei 2017)

Dalam pandangan Boomgaard, seperti yang dikemukakan di atas bahwa sekalipun pelayanan kesehatan (Gambar 4) dilakukan oleh pemerintah di masa kolonial, namun tetap masih memperlihatkan adanya kegagalan dalam menangani wabah malaria. Kasus malaria yang tidak hilang dalam rentang tahun 1930--1939 jelas merupakan sebuah kegagalan kebijakan pemerintah sekaligus kegagalan modernisasi saat itu. Kemunculan wabah malaria telah menjadi bencana sosial berupa terpuruknya perekonomian pemerintah dan kesejahteraan masyarakat. Bahkan, dalam memori ingatan masyarakat, wabah malaria itu bagaikan "penyakit hantu yang menakutkan" dan seperti "malaikat izroil" pencabut nyawa yang tibatiba merenggut nyawa temannya.

Ungkapan itu jelas menggambarkan sebuah bencana besar sebagai dampak dari kegagalan program pemerintah.

\section{SIMPULAN}

Untuk menjawab pertanyaan penelitian, berdasarkan temuan sumber yang telah dideskripsikan, dapat diambil simpulan atas penelitian ini bahwa pada tahun 1930-an kota Cirebon sudah menjadi kota kolonial yang modern. Namun, selama rentang tahun itu, modernisasi tidak menunjukkan keberhasilan yang signifikan akibat kebijakan pemerintah yang tidak ramah lingkungan ketika berbagai infrastruktur dibangun dan diskriminatif terhadap sebagian golongan masyarakat. Dampak dari kegagalan modernisasi pada tahun 1930-an itu, terutama adalah banjir yang terjadi setiap musim penghujan, wabah malaria yang terjadi setiap tahun, dan perekonomian merosot sehingga tidak mampu memberikan subsidi dana kesehatan kepada rumah sakit dan masyarakat. Modernisasi kota yang tidak berorientasi pada kesehatan lingkungan dan kesehatan masyarakat akhirnya menuai bencana sosial berupa meningkatnya jumlah angka kematian (mortalitas) dan angka kesakitan (morbiditas), serta bencana alam, seperti banjir. Pada masa itu modernisasi kota 
adalah fenomena nyata yang dialami masyarakat kota Cirebon pada masa kolonial. Akan tetapi, lingkungan kota yang menjadi harapan masyarakat pribumi sebagai tempat mengadu nasib, pada kenyataannya tidak menjamin hidupnya lebih sejahtera dan sehat. Di hadapan masyarakat pribumi modernisasi kota adalah sebuah kenyataan yang bukan diperuntukkan baginya, yaitu diperuntukan golongan tertentu, seperti Eropa, Cina, Arab, dan para pengusaha. Dalam kondisi itu, ketika wabah malaria menimpa masyarakat pribumi, mereka juga tidak merasakan pelayanan kesehatan yang modern. Itulah yang kemudian menjadikan angka kematian akibat malaria sangat tinggi pada tahun 1930-an itu. Bencana wabah malaria dirasakan masyarakat seperti hantu yang menakutkan. Bahkan, dipandang seperti malaikat izroil pencabut nyawa yang mengincar kematiannya setiap saat.

\section{DAFTAR PUSTAKA}

Bahauddin. (2000a). Dari Mantri hingga Dokter Jawa: Studi Kebijakan Pemerintah Kolonial dalam Penanganan Penyakit Cacar di Jawa Abad XIX-XX. Lembaran Sejarah, 18(3), 11.

Bahauddin. (2000b). Pelayanan Kesehatan Masyarakat pada Masa kolonial. Lembaran Sejarah. http://i-lib.ugm.ac.id/jurnal/detail.php?dataId=7206

Basundoro, P. (2018). Merebut Ruang Kota: Aksi Rakyat Miskin Kota Surabaya 1900-1960-an. Marjin Kiri.

Bataviasch Nieuwsblad. (1930, May 24). Bataviasch Nieuwsblad.

Bataviasch Nieuwsblad. (1939, March 10). Bataviasch Nieuwsblad.

Belshaw, C.S., \& Furnivall, J.S. (1956). Colonial Policy and Practice. A Comparative Study of Burma and Netherlands India. International Journal, 12(1), 70. https://doi.org/10.2307/40198306

Berger, P. L., \& Luckman, T. (2013). Tafsir Sosial Atas Kenyataan: Risalah tentang Sosiologi Pengetahuan. LP3ES.

Boomgard, P. (1993). The Development of Colonial Health Care in Java; An Explanatory Introduction. Bijdragen Tot de Tall-, Land- En, Volkenkunde, 149(1), 77-93.

Boomgard, P., Sciortini, R., \& Smyth, I. (1996). Health Care in Java; Past and Present. Research in African Literatures. https://doi.org/10.2307/2658367

Breman, J. (1986). Penguasaan Tanah dan Tenaga Kerja: Jawa di Masa Kolonial. LP3ES.

De Indisch Courant. (1938, November 2). De Indisch Courant. 
De Preanger Bode. (1917a, Mei). 7 Mei 1917.

De Preanger Bode. (1917b, May). De Preanger Bode.

Depdikbud. (1991). Kamus Besar Bahasa Indonesia. Departemen Pendidikan dan Kebudayaan.

Emalia. (2020a, May 2). Wabah Malaria dan Merosotnya Perekonomian Cirebon Abad XX. Republika Online. https://republika.co.id/share/q9opnz385

Emalia, I. (2020b). Wabah Penyakit dan Penanganannya di Cirebon 1906--1940. Republika Online.

Emalia, I. (2020c, May 2). Wabah Malaria dan Merosotnya Perekonomian Cirebon Abad XX. Republika Online.

Fernando, M. R. (2010). Femine in a Land Of Plenty: Plight of Rice Growing Community in Java 1883-84. Journal of Southeast Asian Studies, 41(1), 291320 .

Hendro, E. P. (2014). Perkembangan Morfologi Kota Cirebon dari Masa Kerajaan Hingga Akhir Kolonial. Paramita Historical Studies Journal, 24(1), 14.

Het Nieuws van der dag voor Netherlandsch Indie. (1937, June 11). Het Nieuws van Der Dag Voor Netherlandsch Indie.

Het Nieuws van der dag voor Netherlandsch Indie. (1938, February 11). Het Nieuws van Der Dag Voor Netherlandsch Indie.

Hingson, R. (1981). In Sickness and in Health: Social Dimensions of Medical Cares. Mosby.

Jaelani, G. A. (2013). Penyakit Kelamin di Jawa 1812-1942. Syabas Books.

Koemandang Masjarakat. (1940).

Napitupulu. (2020). Paradoks Pembangunan (Tesis-Antitesis Pragmatis). https://perpustakaan.setneg.go.id/index.php?p=show_detail\&id=5096

Nugroho, A. S., Kaswinarni, F., \& Prasetio, P. (2012). Pengelolaan Kebersihan dan Kesehatan Lingkungan. Jurnal Pengabdia Kepada Masyarakat, 3(2).

Nursam, M. (2010). Kota-Kota di Jawa: Identitas, Gaya Hidup dan Permasalahan Sosial. Ombak.

Spiegel, G. M. (2005). Practicing History: New Direction in Historical writing After The Linguistic Turn. Psycology Press.

Supratman, F. R. (2013). Menuju Kota Sehat: Usaha Meningkatkan Kualitas Kesehatan di Kota Cirebon Pada Masa Kolonial [Skripsi]. Universitas Indoneisa. 
Trager, F. N. (1957). Colonial Policy and Practice: A Comparative Study of Burma and Netherlands India. By J. S. Furnivall. New York: New York University Press (in cooperation with the Institute of Pacific Relations), 1956. Xiii, 568. Appendices, Index, Map. \$7.50. The Journal of Asian Studies, 16(3), 455-457. https://doi.org/10.2307/2941255 